\title{
Adsorption Capacity and Mineralogical and Physico-Chemical Characteristics of Alluvial Clay from Far-North Cameroon
}

\author{
*Henriette Zangue Adjia ${ }^{1,2}$; Frederic Villieras ${ }^{1}$ and Richard Kamga ${ }^{2}$. \\ ${ }^{1}$ Laboratoire Interdisciplinaire des Environnements Continentaux (LIEC) UMR 7360 CNRS - \\ Université de Lorraine 15 Avenue du Charmois, F-54500@FVillieras : \\ ${ }^{2}$ National School of Agro-Industrial Sciences (ENSAI) University of Ngaoundere B.P. 455 Adamaoua, CAMEROON. \\ University of Ngaoundere p.o box: 455 Adamaoua, Cameroon)
}

\begin{abstract}
In this paper, alluvial clays from far north region of Cameroon has been characterized mineralogically by $\mathrm{X}$-ray diffraction (XRD) and electron microscopy, chemically by oxide compositions, structure formulae, and cation exchange capacity (CEC), and physically by specific surface area and adsorption isotherms. Batch adsorption studies were performed to evaluate the adsorption performance of lead metal $(\mathrm{Pb})$ basic dye on the local clay mineral. The quantitative XRD analysis indicates that the purity of the alluvial clay is very high (about $70 \%$ of the clay minerals are smectite and $30 \%$ are kaolinite). The scanning electron microscopy (SEM) and transmission electron microscopy (TEM) images clearly support this conclusion. The adsorption equilibrium revealed that the alluvial clay from far north region of Cameroon can uptake up to100\% of $\mathrm{Pb}$ per $1 \mathrm{~g}$ mass of clay. $\mathrm{Pb}$ adsorption is best fitted by Langmuir and freundlich isotherms, the Langmuir model represented the sorption process better than the Freundlich one, with correlation coefficient $\left(R^{2}\right)$ values ranging from 0.98 to 0.95 . Satisfactory agreement between experimental data and the model-predicted values was ${ }^{2}$ expressed by the correlation coefficient $\left(\mathbf{R}^{2}\right)$. The adsorption capacity $\left(Q_{0}\right)$ calculated from the Langmuir isotherm was $62.1 \mathrm{mg} \mathrm{Pb}(\mathrm{II}) \mathrm{g}^{-1}$.The Lagergren's first-order rate constants were calculated for different initial concentrations of metal ions. In batch mode adsorption studies, removal increased with an increase of contact time, adsorbent amount and solution $\mathrm{pH}$. The results obtained from these laboratory-scale adsorption tests indicate the promising adsorption capability of the cameronian's far north alluvial clay.
\end{abstract}

Key words: Adsorption, alluvial clay, lead (heavy metal), Physico-chemical characterization.

\section{INTRODUCTION}

Recent industrial revolution in central Africa as Cameroon has enormously increased the industrial wastewater production which is highly contaminated with various types of heavy metals. Heavy metal contamination exists in waste effluents of different factories such as metal plating, mining operations, tanneries, ceramic painting, manufacturing paints, catalysts, alloy industries, galvanizing iron, polymer stabilizer, storage batteries manufacturing, pesticides, wood preservation, pigments factories and families cloths painting (M. C. Basso et al., 2002 ; K. Sundar et al.,2010 ; Arwidsson Z et al.,2010;
Berthelot Y. et al.,2008 ; Cao X. et al.,2008 ; Moon DH. et al.,2010 and Chrastný V. et al.,2010). Heavy metals have been acknowledged as potential health and environmentally hazardous materials. Many studies have shown that these metals are toxic even at low concentrations. The presence of these toxic metals can cause, in turn, accumulative poisoning, destroy liver, cancer and brain damage when found above the tolerance level (Arif et al., 2015 ; Geier et al., 2015 ; Carneiro et $a l ., 2014$; Chen et al., 2012 ; Ilyin et al., 2010 ; Bridges, C.C. et Zalups, R.K., 2010 ; Ilyin et al., 2002, 2003 ; CACAR, 2003 ; Chang,L.W., 1977 ).

Meena et al. (2005) reported that the removal of $\mathrm{Cd}(\mathrm{II})$, $\mathrm{Pb}(\mathrm{II}), \mathrm{Hg}(\mathrm{II}), \mathrm{Cu}(\mathrm{II}), \mathrm{Ni}(\mathrm{II}), \mathrm{Mn}(\mathrm{II})$ and $\mathrm{Zn}(\mathrm{II})$ by carbon aerogel is concentration, $\mathrm{pH}$, contact time, adsorbent dose and temperature dependent. The adsorption isotherm studies clearly indicated that the adsorptive behavior of metal ions on carbon aerogel satisfies not only the Langmuir assumptions but also the freundlich assumptions, i.e, multilayer formation on the surface of the adsorbent with an exponential distribution of site energy. The results indicate the potential application of this method for effluent treatment in industries and also provide strong evidence to support the adsorption mechanism proposed. Erdem et al. (2004) studied the adsorption behavior of natural (clinoptilolite) zeolites with respect to $\mathrm{Co}^{2+}, \mathrm{Cu}^{2+}, \mathrm{Zn}^{2+}$ and $\mathrm{Mn}^{2+}$ in order to consider its application to purity metal finishing wastewater. They found that the adsorption phenomenon depends on charge density and hydrated ion diameter. According to the equilibrium studies, the selectivity sequence can be given as $\mathrm{Co}^{2+}>\mathrm{Cu}^{2+}>\mathrm{Zn}^{2+}$ $>\mathrm{Mn}^{2+}$. These results show that natural zeolites hold great potential to remove cationic heavy metal species from industrial wastewater.

Presently, many techniques such as chemical precipitation, extraction, reverse osmosis and adsorption are being used for the removal of heavy metals from wastewater. Adsorption technique is an economical process especially using low cost adsorbents. Many investigators have evaluated natural clay and the date pits as a low-cost adsorbents due to their adsorption properties for heavy metals including cobalt, lead, cadmium, zinc and chromium 
ions (Ahmad et al., 2011, 2018 ; Sameeh et al., 2016 ; Abdullah A. et al., 2017, Ahmad et al., 2018).

Extensive review of literature indicated that a very little has been accomplished on the contamination levels of various heavy metals in the industrial wastewater in Cameroon and their removal using local clay as adsorbent. It was, therefore, imperative to study the concentration level of lead in the textiles wastewater, possible sources of this heavy metal and to remove it by adsorption from the industrial waste water by using local alluvial clay from far north Cameroon as adsorbent. In fact the batch experiments had been the base in this study to ensure that adsorption equilibrium of the lead.

\section{MATERIAL AND METHODS}

\subsection{Material}

The soil samples were taken in a dry river bed situated between the towns of Maroua and Kaele in the far-north region of Cameroun. The system coordinates of this area is $10^{\circ} 02.883 \mathrm{~N}$ and $014^{\circ} 23.084 \mathrm{E}$. The climate is tropical-dry, characterized by 7- 8 months of dry season and 4- 5 months of wet season. The mean annual rainfall and temperature in the area is $800 \mathrm{~mm}$ and $28.5^{\circ} \mathrm{C}$, respectively. During the wet season the rivers (locally call Mayo) contain running water while in the dry season there is almost no water. The soil depth during the sampling is $99 \mathrm{~cm}$ (Adjia et al., 2013; Adjia et al., 2014).

\subsubsection{Adsorption's material}

The soil fraction was pounded in agathe mortar and then placed in an ultrasound bath for 2 hours. The resulting mixture was then sieved over $50 \mu \mathrm{m}$ mesh sieve. Pure water (MilliQ ultrapure) was used to facilitate the sieving process. The resulting mixture was dried in an oven at $105^{\circ} \mathrm{C}$ until complete evaporation of water. The solid obtained was treated with $5 \%$ hydrogen peroxide solution to eliminate organic matter. Clay fraction $(<2 \mu \mathrm{m})$ was extracted by sedimentation.

\subsection{Methods}

\subsection{1. $X$-ray diffraction (XRD)}

The X-ray diffraction (XRD) data were obtained using a D8 Bruker diffractometer with $\mathrm{CoK} \alpha_{1}$ radiation $(\lambda=1.789$ $\AA$ ). Spectra were recorded on oriented and unoriented samples. The detection limit for a given crystalline phase is estimated at around $1 \%$ in mass. Ethylene glycol and heat treatments $\left(550{ }^{\circ} \mathrm{C}\right)$ were used to provide additional information essential for the identification of clay minerals.

\subsubsection{Scanning and transmission electron microscopy}

TEM observations were carried out with a Philips CM20 microscope equipped with an EDS detector. Secondary and backscattering SEM observations were carried out on a Hitachi 2500 LB SE microscope equipped with a Kevex Delta EDS spectrometer. SEM was used to assist in the identification of individual accessory minerals incorporated in the clay samples by comparing their morphological characteristics with their elemental compositions.

\subsubsection{Chemical analyses}

Chemical analyses were performed on the two clay fractions. The major elements were determined by inductively coupled plasma atomic emission spectroscopy (ICP-AES), while trace elements and rare earths elements were determined by inductively coupled plasma mass spectrometry (ICP-MS).

\subsubsection{Cation Exchange Capacities (CEC)}

Cationic exchange capacities (CEC) were measured using cobaltihexamine $\left[\mathrm{Co}\left(\mathrm{NH}_{3}\right)_{6} \mathrm{Cl}_{3}\right]$ as exchangeable ions. The amount of cobaltihexamine fixed by the solid phase was determined from concentration measurements using UVvis spectroscopy. The displaced cations were determined by atomic absorption spectrometry (Perkin-Elmer 1100B). The equilibrium $\mathrm{pHs}$ of clay suspensions were determined using a standard LPH 330 T electrode.

\subsubsection{Textural properties}

Nitrogen adsorption-desorption isotherms at $77 \mathrm{~K}$ were recorded on a step-by-step automatic home-built set up. Pressures were measured using 0-1000 $\mathrm{Pa}$ and 0-100.000 $\mathrm{Pa}$ Baratron-type pressure sensors provided by Edwards. The nitrogen saturation pressure was recorded in situ using an independent 0-100.000 Pa Baratron-type pressure sensor provided by Edwards. Prior to adsorption, the samples were out gassed overnight at $120^{\circ} \mathrm{C}$ and under a residual pressure of $0.01 \mathrm{~Pa}$. Nitrogen N55 (purity > 99.9995\%) used for experiments was provided by alphagaz (France). Specific surface areas (SSA) were determined from adsorption data by applying the Brunauer-Emmet-Teller (BET) equation and using $16.3 \AA^{2}$ for the cross sectional area of nitrogen. In the present study, the error in the determination of the SSA was estimated as $+/-1 \mathrm{~m}^{2} / \mathrm{g}$. Micropores volumes and non microporous surface areas were obtained using the t-plot method proposed by De Boer et al., (1996). Pore size distributions were calculated on the desorption branch using the Barrett-Joyner-Halenda method, assuming slit-shaped pores.

2.2.6. Experimental procedures

Stock solutions (500 $\mathrm{mg}^{-1}$ ) of $\mathrm{Pb}$ ( II), was prepared by dissolving the appropriate amounts of analytical reagent grade $\mathrm{Pb}\left(\mathrm{NO}_{3}\right)_{2}$, respectively, in ultrapure water. The stock solutions were diluted as required to obtain standard solutions containing $20-100 \mathrm{mg} / \mathrm{L}$ of $\mathrm{Pb}(\mathrm{II})$. Adsorption measurements were made by a batch technique at room temperature $\left(25 \pm 1^{\circ} \mathrm{C}\right)$. The batch mode was selected because of its simplicity and reliability. Known amounts of alluvial clay were placed in different stoppered Erlenmeyer glass flasks of $100 \mathrm{ml}$ capacity containing $50 \mathrm{ml}$ of metal ion solution of known concentration and $\mathrm{pH}$. All experiments were carried out at $\mathrm{pH} 7.0$ (except when the effect of $\mathrm{pH}$ was studied). The $\mathrm{pH}$ of each solution was adjusted to the desired value by addition of dilute $\mathrm{HCl}$ or $\mathrm{NaOH}$ solutions. The solutions were shaken vigorously for a given time period to reach equilibrium. The agitation speed was kept constant for each run to ensure equal mixing. After completion of a pre-selected shaking time, 
the flasks containing the sample were withdrawn from the shaker, the suspensions were then filtered using filter paper (gravitational filtration), an $\mathrm{d}$ the supernatant solution in each flask was analyzed by atomic absorption spectrometry (AAS) for its residual metal content. Langmuir and Freundlich isotherm models were fitted to the adsorption data and their constants were evaluated. Satisfactory conformity between experimental data and the model- predicted values was expressed by the correlation co efficient $\left(\mathrm{R}^{2}\right)$. Throughout the study, the co $\mathrm{n}$-tact time was varied from 1 to $35 \mathrm{~min}$, the $\mathrm{pH}$ from 3.0 to 10 , and the initial metal ion concentration from 20 to $100 \mathrm{mg} / \mathrm{L}$ and the amount of adsorbent from 0.1 to $1 \mathrm{~g}$.

\section{RESULTS AND DISCUSSION}

\subsection{X-ray diffraction}

XRD patterns of alluvial clay samples show that it consists predominantly in smectite, kaolinite and quartz, with accessory minerals such as anatase, microcline, albite and rutile (Figure 1a). The results of the ethylene glycol test on oriented clay fraction showed the characteristic displacement of the basal peak of smectite from 15.2 to $18.3 \AA$ (Figure 1b). The usual displacement of the smectite from 15.2 to $10.1 \AA$ on heating at $550^{\circ} \mathrm{C}$ is also observed. All the vertisol profiles in this area showed a similar mineralogical composition; however Adjia et al. (2013; 2014) found that most of the smectite minerals of the vertisol soil of this zone are mixtures of montmorillonite and beidellite. The spectra of the A50 fraction show a well defined peak of quartz indicating a high amount of quartz in this sample. On the contrary the clay fraction only presents very few amount of quartz.
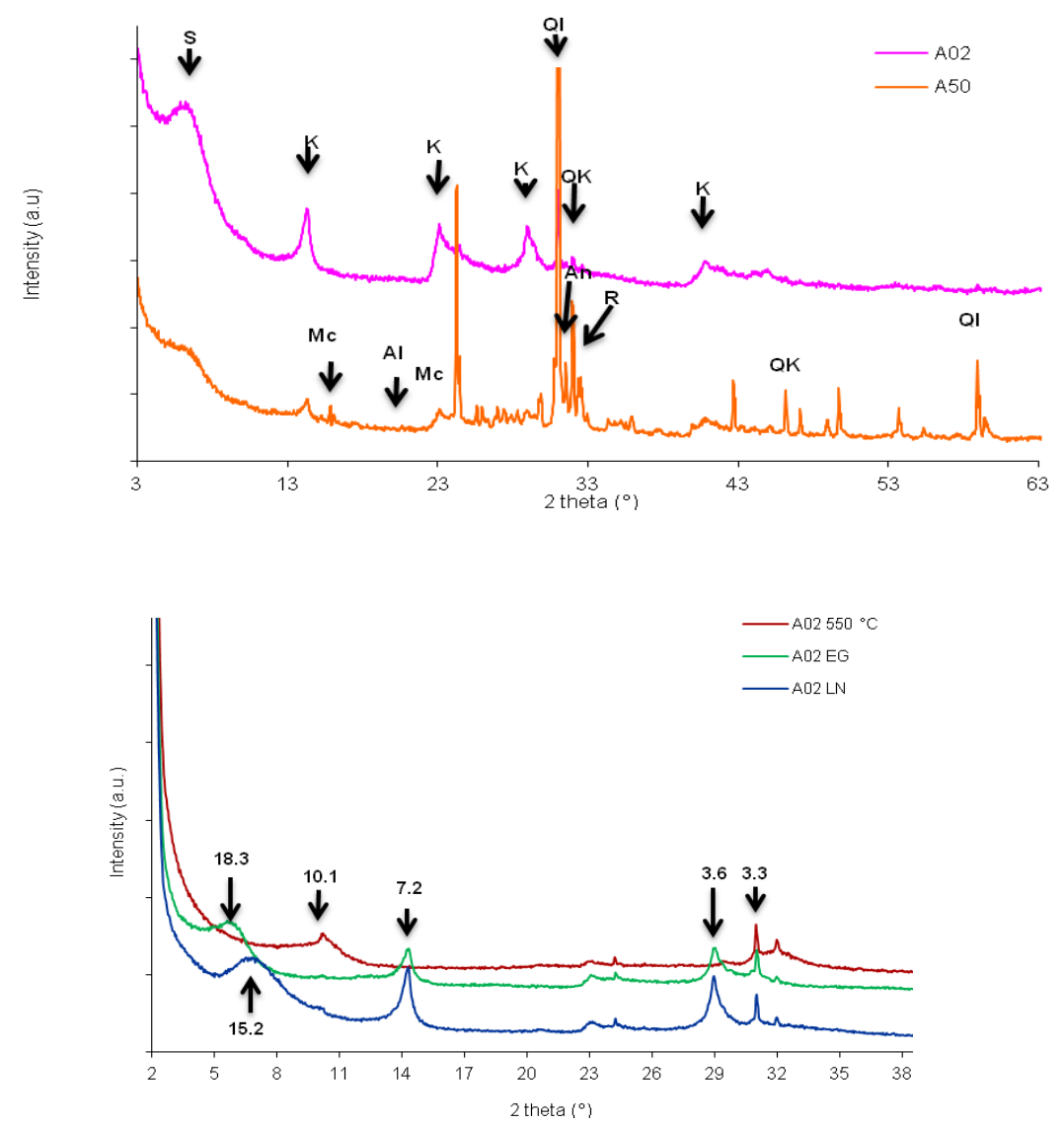

Fig. 1.: X-ray diffraction patterns of a) natural (A02, A50), b) oriented preparation of clay fraction (A02 LN), (A02 EG), (A02 550 $\left.{ }^{\circ} \mathrm{C}\right)$. Basal spacings on fig.1b are given in $\AA$. Nomenclature (S: smectite ; K : kaolinite ; Mc : microcline ; $\mathrm{Al}$ : albite ; Q : quartz ; An : anatase ; R : rutile)

\subsection{Scanning and transmission electron microscopy}

SEM observation on a polish slide of A50 fraction shows large aggregates and small particles dispersed over the entire matrix (Figure 2a). SEM with EDX analysis of the aggregates reveal the presence of smectite [A]: $(\mathrm{Si} / \mathrm{Al} \approx 0.60)$, of microcline $[\mathrm{B}]:(\mathrm{Si} / \mathrm{Al} \approx 2.8$ and 3$)$, of quartz $[\mathrm{C}]:(\mathrm{Al}=0)$, of interstratified $[\mathrm{D}]:(\mathrm{Si} / \mathrm{Al} \approx 1.6)$ and of kaolinite $[\mathrm{E}]:(\mathrm{Si} / \mathrm{Al} \approx 2)$. Those minerals have currently been identified from XRD and IR analyses. The SEM images of A50 powder shows the usual cluster of rose shaped aggregates of smectite particles (Figure 2b). TEMEDX analysis confirms the presence of kaolinite and smectites; they also reveal the additional presence of quartz, feldspar and iron oxy-hydroxides as minor phases (Figure 2c). Adjia et al., (2013). 

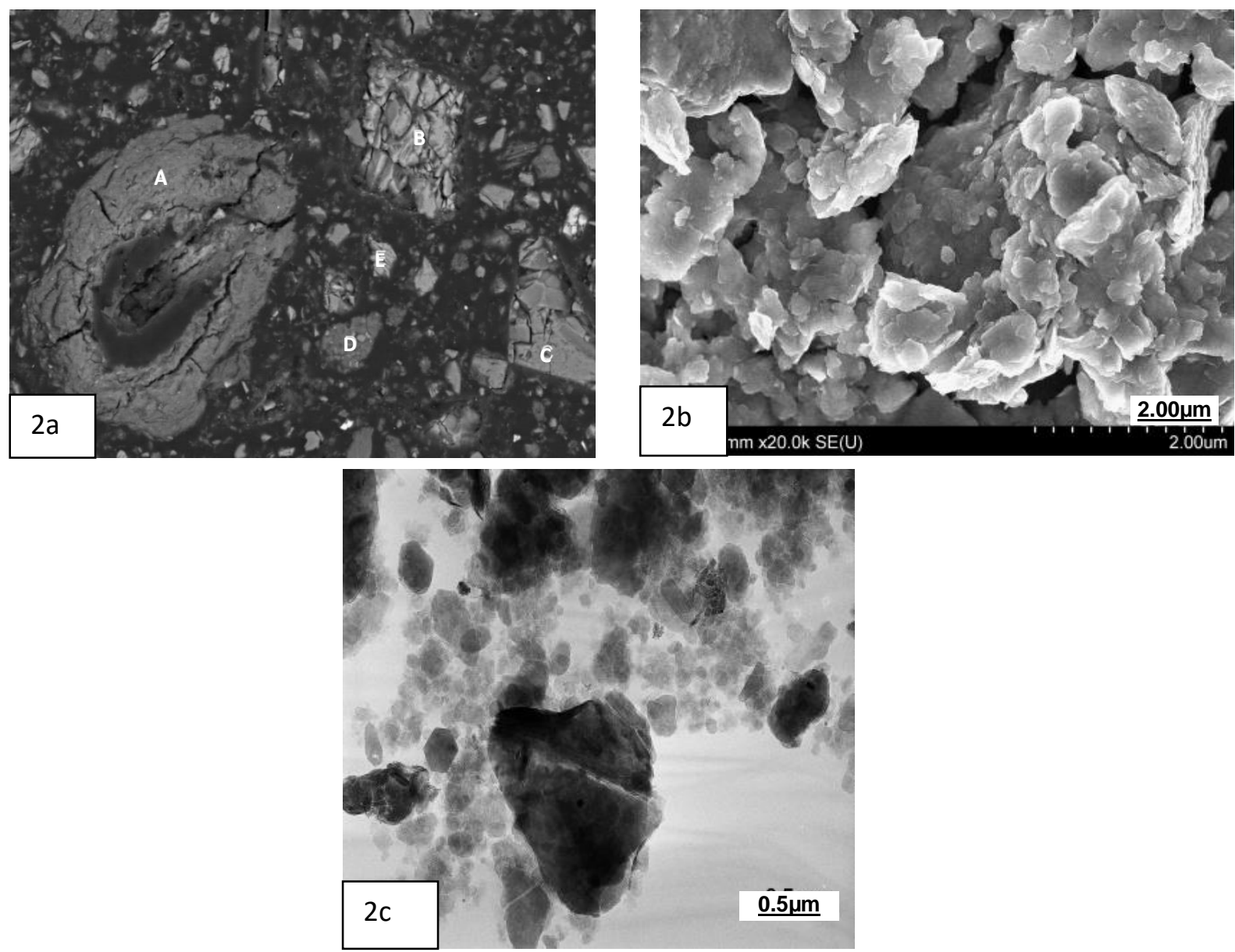

Fig.2.: Scanning electron photomicrograph (SEM) and TEM micrograph of alluvial clayey fraction, showing typical texture.2a) SEM A50 (polished slide of clay embedted in resins); 2b) SEM A50 (powder) ; 2c) TEM A02. Minerals identification is derived from EDX analyses.

3.3. Physico-chemical characteristics of the alluvial clayey soil from Far North Cameroon

The cation exchange capacity (CEC) values measured from variation in concentration of cobatihexamine match those deduced from the chemical analysis of exchangeable cation for all the samples described herein. This confirms the absence of soluble phases in the studied fraction. The CEC of the clay fraction (Table 1) lie between the values reported in the literature for smectite that is 60 to 150 meq/100 g (Adjia et al., 2014). The lower CEC value for
A50 fraction compared to clay fraction correlates with its lower content in clays. Indeed, the CEC ratio between A50 and $\mathrm{A} 02$ is 0.54 , in good agreement with the $57 \%$ of clays in A50. From the analyses of the cations exchanged with cobaltihexamine, it can be concluded that around $2 / 3$ of the layer charge is compensated by divalent cations $\left(\mathrm{Ca}^{2+}\right.$ and $\left.\mathrm{Mg}^{2+}\right)$. The observed decrease in CEC can be assigned to a decrease in swelling capacities of $\mathrm{H}^{+}$with migration into interlayers (Adjia et $a l ., 2013$ ).

Table 1: Equilibrium pH, cation exchange capacities (CEC), and exchangeable cations of the clay fraction.

\begin{tabular}{|c|c|c|c|c|c|c|c|}
\hline Samples & $\begin{array}{l}\text { pH } \\
\pm 0,1\end{array}$ & $\begin{array}{l}\text { CEC } \\
\text { (chem) } \\
\text { meq/100g } \\
\pm 5\end{array}$ & $\begin{array}{l}\text { CEC (UV) } \\
\mathrm{meq} / 100 \mathrm{~g} \\
\pm 5\end{array}$ & $\begin{array}{l}\mathrm{Na}^{+} \\
\text {(meq/100g) } \\
\pm 2\end{array}$ & $\begin{array}{l}\mathrm{K}^{+} \\
\text {(meq/100g) } \\
\pm 1\end{array}$ & $\begin{array}{l}\mathrm{Ca}^{2+} \\
\text { (meq/100g) } \\
\pm 2\end{array}$ & $\begin{array}{l}\mathrm{Mg}^{2+} \\
(\mathrm{meq} / 100 \mathrm{~g}) \\
\pm 1\end{array}$ \\
\hline A02 & 9.2 & 58 & 62 & 14.8 & 1.5 & 29.2 & 13.0 \\
\hline A50 & 9.5 & 31 & 34 & 6.3 & 0.6 & 15.8 & 6.3 \\
\hline
\end{tabular}

Note Chem: derived from chemical analysis of displaced cations. UV: derived from the measurement of cobaltihexamine concentrations by UV-visible spectroscopy. 


\subsection{Specific surface area}

\subsubsection{Textural properties}

The adsorption-desorption isotherms on the four samples are reported in Figure $\mathbf{3}$ are typical of clay materials containing smectites (Neaman et al., 2003). Numerical values deduced from the adsorption and desorption isotherm are given in Table 2 . The difference in the specific surface areas (SSA) of A02 and A50 fractions can be attributed to their quartz content. In fact A50 fraction has contains a large amount of quartz, and quartz particles present low specific surface areas compared to clays. Indeed, the 0.54 SSA ratio between A50 and A02 samples is also consistent with CEC and clay content of A50 showing that sandy fraction of A50 has no surface area. Microporosity represent about $20 \%$ of the total surface area and can be assigned to clay layers organisation as it is generally observed in the case of swelling clays with divalent exchangeable cations (Neaman et al., 2003).

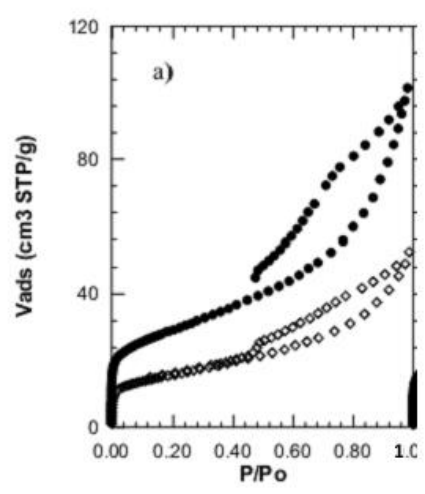

Fig. 3. : Nitrogen adsorption and desorption isotherms at 77K. For a)clay fraction (A02) and sandy fraction (A50) •: A02; $\diamond:$ A50.

Table 2: Textural parameters deduced from $\mathrm{N}_{2}$ adsorption desorption isotherms (SSA: specific surface area).

\begin{tabular}{|c|c|c|c|c|c|}
\hline Samples & $\begin{array}{l}\text { BET C } \\
\text { Constant }\end{array}$ & $\begin{array}{l}\text { BET SSA } \\
\left(\mathrm{m}^{2} / \mathrm{g}\right) \\
\pm 1\end{array}$ & $\begin{array}{l}\text { Non } \\
\text { Microporous } \\
\text { surface area } \\
\left(\mathrm{m}^{2} / \mathrm{g}\right) \\
+1\end{array}$ & $\begin{array}{l}\text { Microporous } \\
\text { equivalent } \\
\text { surface area } \\
\left(\mathrm{m}^{2} / \mathrm{g}\right) \\
+1\end{array}$ & $\begin{array}{l}\text { Microporous } \\
\text { Volume }\left(\mathrm{cm}^{3} / \mathrm{g}\right) \\
\pm 0,0003\end{array}$ \\
\hline A02 & 215 & 103 & 82 & 26 & 0.0091 \\
\hline A50 & 337 & 56 & 44 & 15 & 0.0053 \\
\hline
\end{tabular}

Note SSA: specific surface area.

\subsubsection{Structural formula of an alluvial clayey soil from Far-North of Cameroon}

The previous characterization analyses show consistent results for the content of clay in the A50 sample. Indeed results derived from the particle size separation has a yield of $57 \%$, whereas BET, CEC, TEM and thermal analysis give 54, 55 and $59 \%$ respectively. The agreement of the results indicates that the clay fraction A02 extracted from the sample A50 is representative of the entire clay fraction initially present. The quantitative mineralogical study of the clay fraction A02 can give an objective estimate in the content of the reactive fraction of the sample. Thus the reactive fraction of the studied alluvial clay (A02) is mainly composed of disordered kaolinite and interstratified smectite / kaolinite. Its surface area is $104 \mathrm{~m}^{2} / \mathrm{g}$ and its CEC is $62 \mathrm{meq} / 100 \mathrm{~g}$. Quantitative mineralogical analysis of the sample of the reactive fraction may be derived from TEM. The atomic percentages of elements obtained from the EDS analyses coupled with the TEM images permit to calculate the $\mathrm{Si} / \mathrm{Al}$ ratio and also to identify the different phases present in the alluvial clay. The obtained analyses are ploted in a Al-Si-Fe ternary diagram (Figure 4) which highlights the presence of some accessory minerals and shows that all clay particle analyses are spread on a mixture straight line, between kaolinite pole and smectite pole. 
These analyses allow us to propose a structural formula for kaolinite: $\mathrm{Si}_{2} \quad \mathrm{Al}_{1.95} \mathrm{Fe}_{0.05} \mathrm{O}_{5}(\mathrm{OH})_{4}$, with significant iron content which is in agreement with the disorganized nature observed by infrared spectroscopy. Assuming that the reference smectite pole on the Al-Si-Fe ternary diagram is pure and contains no kaolinite, smectite structural formula can be calculated is: $\left[\mathrm{Si}_{3.42} \mathrm{Al}_{0.58}\right]$ tetra $\left[\mathrm{Al}_{0.87} \mathrm{Fe}_{0.96}\right.$ $\left.\mathrm{Mg}_{0.17}\right]_{\text {octaO }}(\mathrm{OH})_{2}\left(\mathrm{C}^{+}\right)_{0.75}$. The calculated smectite has a double character beidellite-smectite with tetrahedral charge of 0.58 greater than the octahedral charge of 0.17 . Its calculated weight loss and CEC are $4.5 \%$ and 186 meq/100 g, respectively. From structural, CEC and chemical analyses, it can be concluded that all the calcium and sodium of A02 are in exchangeable position whereas $75 \%$ of $\mathrm{Mg}$ is in octahedral position and less than $10 \%$ of $\mathrm{K}$ is exchangeable. This smectite can then be considered as a high charge smectite with limited swelling capacities due to the presence of non-swelling layers with dehydrated $\mathrm{K}^{+}$ interlayers as already observed by Mosser-Ruck et al., (2001) for other high charge smectites. From the elemental compositions of kaolinite and smectite endmembers, it is possible to calculate the percentage of these two phases in mixed particules. The structural formulas of smectite and kaolinite being established, it is possible to estimate their quantitative proportions (Table 3) by making the assumption that the feldspar and iron oxy-hydroxide are negligible in quantity, which is not the case for quartz visible by XRD. Least squares estimation of quartz, kaolinite and smectite was carried out from the contents in $\mathrm{Si}, \mathrm{Al}, \mathrm{Mg}$ and $\mathrm{Fe}$ of the chemical analysis Adjia et al., (2014). The results obtained are shown in Table 3 with an error margin of 3 to $5 \%$ for quartz, kaolinite and smectite. At this stage, it is not possible to clearly make the differences between pure kaolinite and kaolinite in mixedlayer kaolinite-smectite particles. The estimated weight for dehydroxylation of the mixture is $7.3 \%$ which is consistent with the results of TG in the range of $8.0 \%$. Theoretical CEC of dehydrated product is $96 \mathrm{meq} / 100 \mathrm{~g}$ which is well above the CEC measured around $62 \mathrm{meq} / 100 \mathrm{~g}$ (Table 1 above). This last result confirms that there are nonswelling layers in A02 as suggested by the strong structural charge calculated for the smectite pole on the ternary diagram. The CEC ratio shows that the percentage of nonswelling layers is about 35\% Adjia et al., (2013).

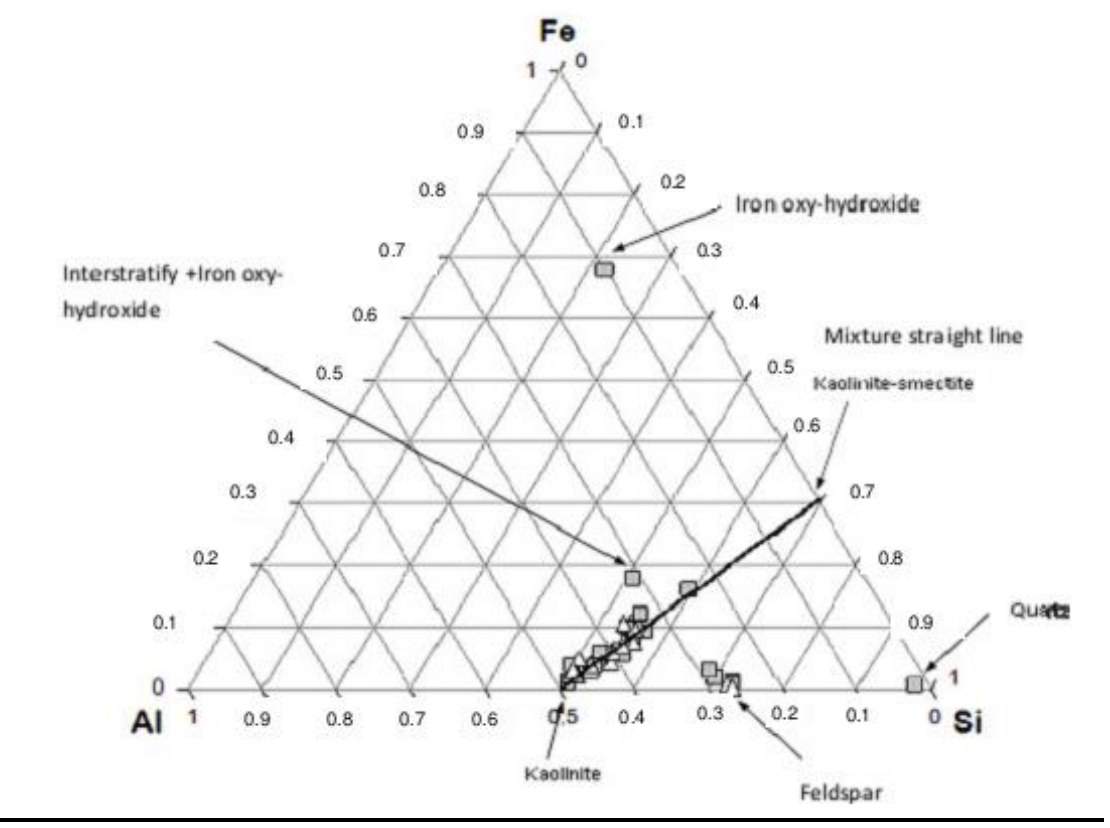

Fig. 4: Al-Si-Fe ternary diagram elemental analyses obtained by EDS in TEM on particulate samples A02 $(\Delta)$ and A02A (匹).

Table 3 : Proportion of quantitative mineralogical phases present in the alluvial clay.

\begin{tabular}{lr}
\hline A02 & Mass \% \\
\hline quartz & 5 \\
kaolinite & 38 \\
smectites & 46 \\
TIO $_{2}$ & 1 \\
autres & 1 \\
hydratation & 9 \\
Total & 100 \\
\hline
\end{tabular}




\subsection{Adsorption's phenomena}

\subsubsection{Effect of shaking time}

The time dependent behavior of lead was measured by varying the equilibrium time between the adsorbate and adsorbent in the range of $1-35 \mathrm{~min}$. The concentration of metal ions was varied from 20 to $100 \mathrm{mg} / \mathrm{L}$. The $\mathrm{pH}$ was kept as 7.0 while the amount of alluvial clay added was 0.1 . (Figure 5) shows the effect of shaking time and initial $\mathrm{pb}$ (II) ion concentration on adsorption from solution when using alluvial clay. Results show that the equilibrium is reached quickly (only $30 \mathrm{~min}$ ), indicating that the adsorption sites are well exposed. Orumwense (1996), using a kaolinitic clay for the removal of lead from water by adsorption, found that the equilibrium time needed for $\mathrm{Pb}$ (II) was longer than is shown by the (Figure 5). However, the results from Esmaili et al. (2003) were similar to those found in this investigation. The latter authors conducted experiments on adsorption of lead and zinc ions from aqueous solutions by volcanic ash soil. As can be observed from the graph, an increasing concentration of the lead ions in solution resulted in an increase of the equilibrium time. It is clear from the results that the shaking time required for maximum uptake of metal ions by alluvial clay was dependent on the initial $\mathrm{Pb}$ (II) concentration. Consequently, the shaking time was fixed at $30 \mathrm{~min}$ for the rest of the batch experiments to ensure that adsorption equilibrium was reached in each case. It also shows that increases in initial metal ion concentration increased the amount of metal ion uptake per unit weight of alluvial clay $(\mathrm{mg} / \mathrm{g})$, as was expected. This finding is in agreement with the results of Ulmanu et al. (2003), who investigated heavy metals from aqueous solution using peat. Generally in others authors, we observed that the differences between the various metal ions can be attributed to the difference in the chemical characteristics of each metal ion investigated.

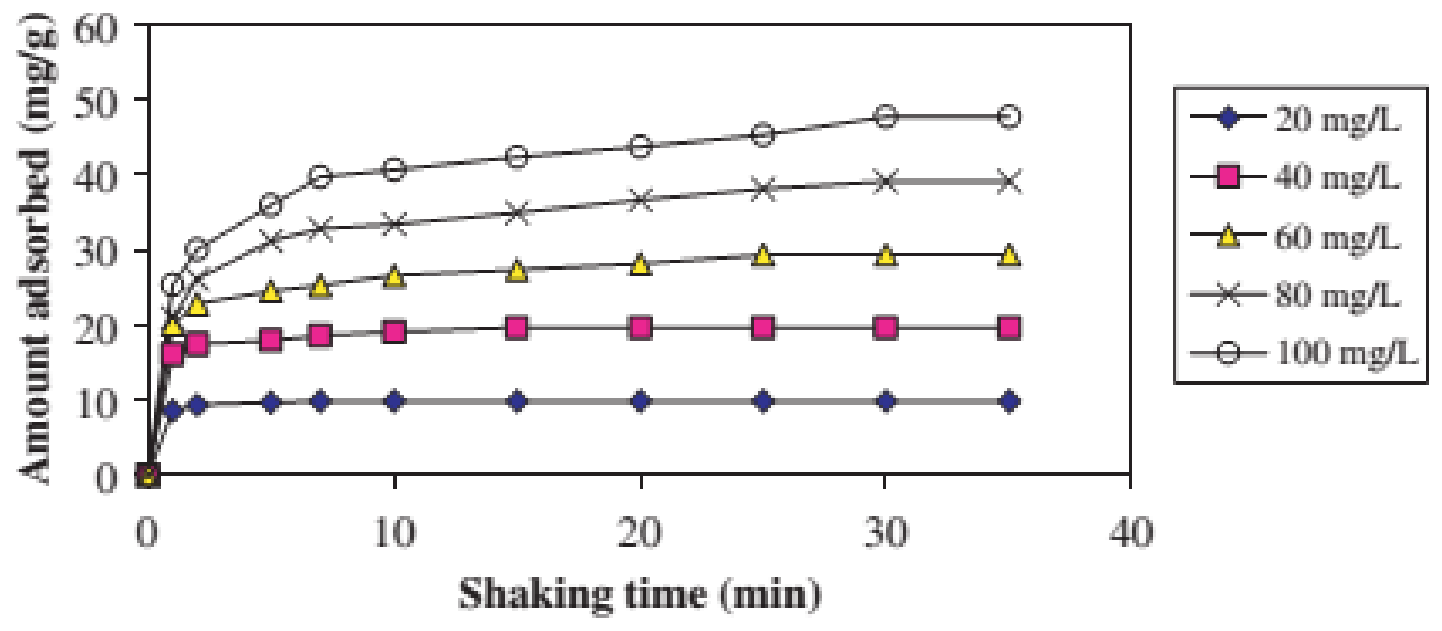

Fig.5: Effect of shaking time and initial $\mathrm{Pb}$ (II) concentration on the adsorption of $\mathrm{Pb}$ (II). Contact time 1-35 min.

\subsubsection{Effect of amount of adsorbent}

The results of the dependence of $\mathrm{Pb}$ (II) adsorption on amount of alluvial clay used are shown in (Figure 6). Increasing the mass of alluvial clay slightly increased the percentage removal of $\mathrm{Pb}(\mathrm{II})$. This is an expected result because as the amount of adsorbent increases, the number of adsorbent sites increases; therefore, these particles attach more ions to their surfaces. Naseem and Tahir (2001) reported similar findings for $\mathrm{Pb}$ (II) removal from aqueous/acidic solutions by using bentonite as an adsorbent.

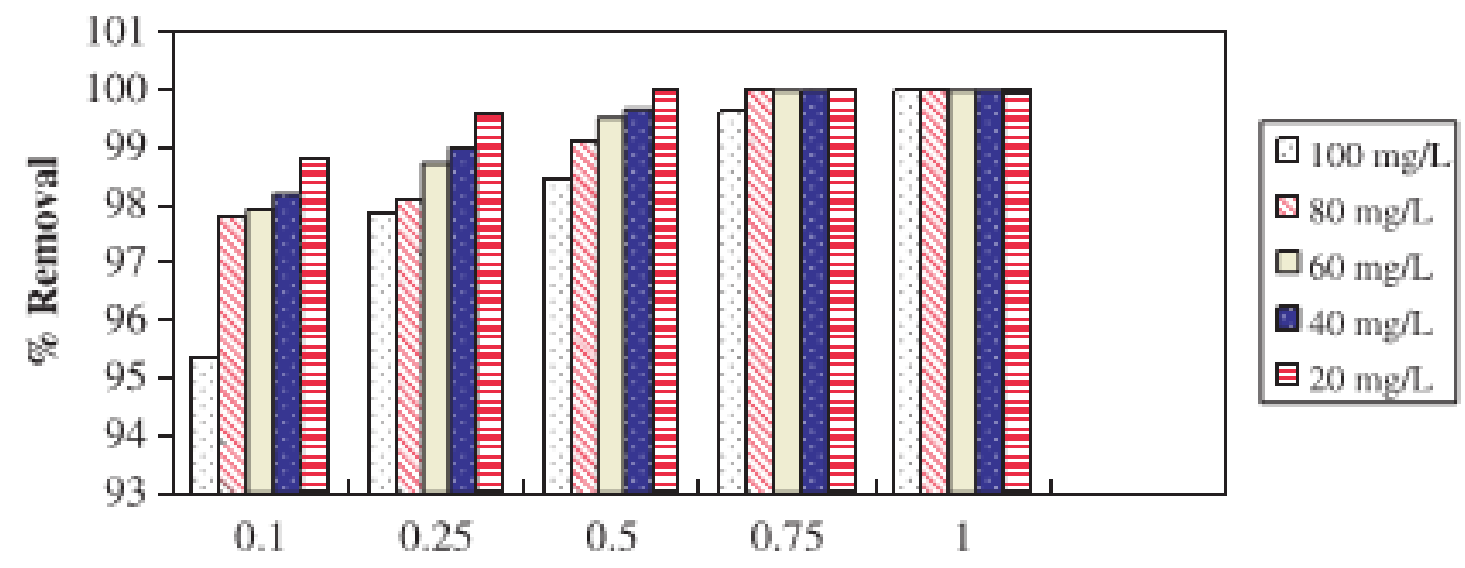

Fig.6: Effect of the mass of alluvial clay on the adsorption of $\mathrm{Pb}$ (II) onto alluvial clay. 


\subsubsection{Effect of amount of $\mathrm{pH}$ on metal ion removal}

The $\mathrm{pH}$ of the aqueous solution is an important variable which controls the adsorption of the metal at the clay-water interfaces. Hence, the influence of $\mathrm{pH}$ on the adsorption of $\mathrm{Pb}$ (II) onto alluvial clay was investigated in the $\mathrm{pH}$ range of 3-10. In this (Figure 7), It can be observed from the results that the adsorption of $\mathrm{Pb}$ ion increases with an increase in $\mathrm{pH}$ of the solution to a maximum around a neutral $\mathrm{pH}$ or slightly basic $\mathrm{pH}$, and then decreases as the $\mathrm{pH}$ becomes more basic. Clays are known to possess a negative surface charge in solution. As $\mathrm{pH}$ changes, surface charge also changes, and the sorption of charged species is affected (attraction between the positively charged metal ion and the negatively charged clay surface). It is conceivable that at low $\mathrm{pH}$ values, where there is an excess of $\mathrm{H}_{3} \mathrm{O}^{+}$ions in solution, a competition exists between the positively charged hydrogen ions and metal ions for the available adsorption sites on the negatively charged clay surface. As the $\mathrm{pH}$ increases and the balance between $\mathrm{H}_{3} \mathrm{O}^{+}$ and $\mathrm{OH}^{-}$are more equal, more of the positively charged metal ions in solution are adsorbed on the negative clay surface and thus the percentage removal of the metal ions increases. This is in agreement with work by other authors (Coetzee et al., 2003) on this same type of clay. On the other hand, precipitation of metal hydroxides may also occur as the $\mathrm{pH}$ in solution increases, which will lead to a corresponding decrease in the amount of metal ions adsorbed onto clay. The experimental results of $\mathrm{Pb}$ ions adsorption onto alluvial clay are in agreement with those of other workers (Orumwense, 1996; Esmaili et al.,2003).

The effect of $\mathrm{pH}$ can be explained in terms of pHzpc (zero point of charge) of the adsorbent. This explanation may be also valid for the adsorption of other metal ions investigated in this work. Below this pHzpc, the surface charge of the adsorbent is positive. An increase in $\mathrm{pH}$ above pHzpc shows a slight increase in adsorption in which the surface of the adsorbent is negatively charged and the sorbate species are still positively charged. The increasing electrostatic attraction between positive sorbate species and adsorbent particles would lead to increased adsorption of metal ions (Kadirvelu et al., 2001).

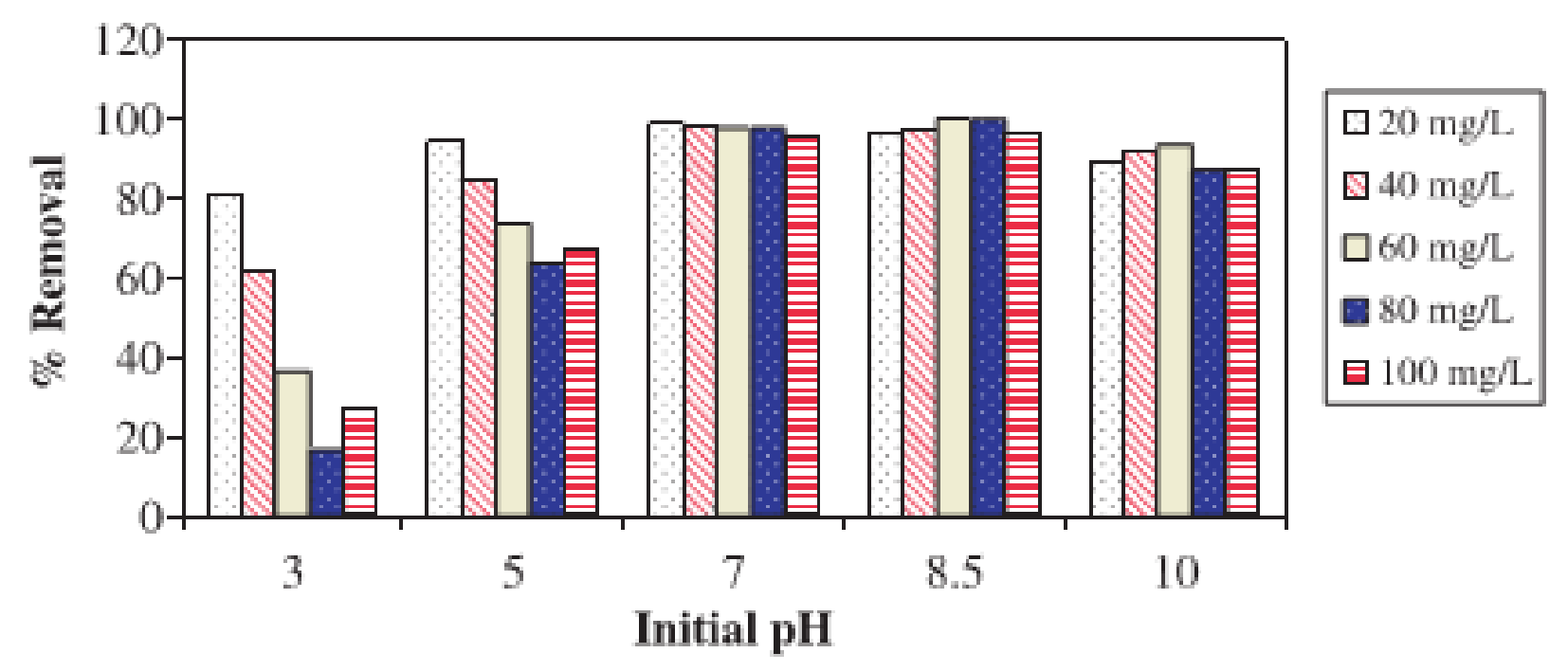

Fig.7: Effect of the $\mathrm{pH}$ on adsorption mass of $\mathrm{Pb}(\mathrm{II})$ onto alluvial clay.

\subsubsection{Adherence to adsorption isotherms}

The adsorption isotherms for $\mathrm{Pb}$ (II) removal were studied using initial concentrations of metal ions between 20 and $100 \mathrm{mg} / \mathrm{L}$ at adsorbent mass of $0.1 \mathrm{~g}$ at room temperature $\left(25 \pm 1^{\circ} \mathrm{C}\right)$. The data obtained were fitted to the Langmuir and freundlich isotherms. The data obtained from the various plots as summarized in (Table 4) show that adsorption of $\mathrm{Pb}$ (II) follow the Langmuir isotherm model fairly well. The adsorption data of all the metal ions also fit the Freundlich isotherm reasonably well, but not as well as the Langmuir equation. According to Tryball (1980), it has been shown using mathematical calculations that $n$ values of between 1 and 10 for the Freundlich isotherm indicate effective adsorption. A summary of the corresponding values of the Langmuir and Freundlich isotherm constants and correlation coefficient $\mathrm{Pb}(\mathrm{II})$ is given in (Table 4). 
Table 4: Langmuir and Freundlich constants and correlation coefficients associated with adsorption isotherms of $\mathrm{Pb}$ (II) onto alluvial clay.

\begin{tabular}{ccccccc}
\hline & \multicolumn{3}{c}{ Langmuir equation } & \multicolumn{3}{c}{ Freundlich equation } \\
\hline & $\mathrm{Q}_{0}(\mathrm{mg} / \mathrm{g})$ & $\mathrm{b}(\mathrm{l} / \mathrm{mg})$ & $\mathrm{R}^{2}$ & $\mathrm{~K}_{\mathrm{f}}$ & $\mathrm{n}$ & $\mathrm{R}^{2}$ \\
$\mathrm{~Pb}$ (II) & 62.11 & 0.75 & 0.9866 & 23.89 & 1.80 & 0.9525 \\
\hline
\end{tabular}

\subsubsection{First-order adsorption kinetic model}

Kinetics of sorption describing the solute uptake rate, which in turn governs the residence time of the solution in an adsorption column or reactor, is one of the important characteristics defining the efficiency of sorption (Yi et al., 2004). Hence, the kinetic parameters for the adsorption process were studied on the batch adsorption of 20 to 100 $\mathrm{mg} / \mathrm{L}$ of metal ions at room temperature at initial $\mathrm{pH}$ ranging from 3.0 to 10.0. The data were fitted to the firstorder Lagergen equation (Da Costa et al.,2003).

$$
\log (q e-q)=\log q e-\frac{\mathrm{K} 1, \mathrm{ads}}{2.303 \times \mathrm{t}}
$$

Where $\mathrm{q}_{\mathrm{e}}(\mathrm{mg} / \mathrm{g})$ is the amount of adsorbed metal ions on the clay at equilibrium, $\mathrm{q}$ is the amount of adsorbed metal ions at any time $\mathrm{t}, \mathrm{K}_{1}$, ads is the Lagergren first order rate constant. In order to fit Eq (1) to experimental data, the equilibrium sorption capacity, qe, must be knowing (Ho and McKay, 1998). The adsorption rate constants (k) were calculated from the slopes of the plots constructed from Eq.(1) for each of the metal ions under investigation and the results are summarized in (Table5). The ionic radius of the metal ions and charge intensity, which affects the accessibility of the metal ions to the surface of pores, must be considered (Uyanik et al., 2004). The smaller the ionic radius and the greater the valence, The more closely and strongly is the ion adsorbed (McKay et al., 2004) onto the clay. The charge to radius ratio (Z/r) or ionic potential (IP) of each of these metal ions is shown in (Table 6). For the cationic metal ions, there is a direct relationship between the $\mathrm{Z} / \mathrm{r}$ ratio and the adsorption rate constant, which is in agreement with other literature reports (Uyanik et al., 2004).

Table 5 : Adsorption rate constants and coefficients of correlation associated with the Lagergen first-order kinetic models $(\mathrm{pH}$ 7.0)

\begin{tabular}{ll}
\hline $\mathbf{K}_{\mathbf{1}, \mathbf{a d s}}\left(\mathbf{m i n}^{-1}\right)$ & $\mathbf{R}^{\mathbf{2}}$ \\
\hline $\mathbf{P b}$ (II) & $\mathrm{Pb}$ (II) \\
$\mathbf{0 . 1 7 \pm 0 . 0 2}$ & 0.94 \\
\hline
\end{tabular}

Table 6: Charge to radius ratio (Z/r) of $\mathrm{Pb}$ (II)

\begin{tabular}{lll}
\hline Ion & Ionic radius $(\AA)$ & $\mathbf{Z}^{\text {a }} /$ ionic radius \\
\hline $\mathrm{Pb}(\mathrm{II})$ & 1.19 & 1.68 \\
\hline
\end{tabular}

\section{CONCLUSION}

A very important clay mineral in the far north of Cameroon has been mineralogically, chemically, and physically characterized. The adsorption capacity of the clay with regard to lead has also been investigated. The quantitative mineralogical investigation on alluvial clay clearly indicates its high purity with smectite minerals that exceeds 40\%. SEM and TEM images clearly indicate the existence of smectite as a dominant mineral in alluvial clay. The overall formula of the clay mineral which was established are: $\quad$ smectite, $\quad\left[\mathrm{Si}_{3.42} \mathrm{Al}_{0.58}\right]_{\text {tétra }}\left[\mathrm{Al}_{0.87} \mathrm{Fe}_{0.96}\right.$ $\left.\mathrm{Mg}_{0.17}\right]_{\text {octa }} \mathrm{O}_{10}(\mathrm{OH})_{2}\left(\mathrm{C}^{+}\right)_{0.75} ; \quad$ and kaolinite, $\mathrm{Si}_{2} \mathrm{Al}_{1.95} \mathrm{Fe}_{0.05} \mathrm{O}_{5}(\mathrm{OH})_{4}$ (Adjia et al., 2013). Alluvial clay was used as a sorbent for the removal of lead from synthetic water preparation in laboratory. In batch mode adsorption studies, removal of metal ion increased with the increase of contact time, amount of adsorbent and $\mathrm{pH}$. The increase in initial metal ion concentration decreased the percent adsorption and increased the amount of metal uptake per unit weight of the sorbent $(\mathrm{mg} / \mathrm{g})$. The equilibrium data could be described by the Langmuir and Freundlich isotherm equations. However, the Langmuir model better represented the sorption process than the Freundlich model. Kinetic modeling results showed that the Lagergrens first- order equation was appropriate for the description of this type of adsorption and removal. For industrial applications, one will have to compliment the batch results with those from columns to derive the necessary design data (WHO, 2011).

\section{AKNOWLEDGMENTS}

The authors are grateful to the FRENCH embassy Trust for their financial support during this study. Our gratitude is extended to University of Lorraine (NANCY-France) for 
making available the materials and facilities for the completion of this work. In particular, special thanks to Mr. Frederic VILLIERAS for his assistance with analysis of samples using his laboratory.

\section{REFERENCES}

[1] Abdullah Aldawsari, Moonis Ali Khan, B. H. Hameed, Ayoub Abdullah Alqadami, Masoom Raza Siddiqui, Zeid Abdullah Alothman, A. Yacine Badjah Hadj Ahmed, (2017). Mercerized mesoporous date pit activated carbon-A novel adsorbent to sequester potentially toxic divalent heavy metals from water.

[2] Adjia H. Zangué, F. Villiéras, R. Kamga and F. Thomas, (2013). Mineralogy and physico-chemical properties of alluvial clays from far-north region of Cameroon: A tool for an environmental problem. International Journal of Water Resources and Environmental Engineering Vol. 5(1), pp. 54-66, January 2013 Available online at http://www.academicjournals.org/IJWREE DOI: 10.5897/IJWREE12.117 ISSN 1991-637X @2013 Academic Journals.

[3] Adjia H. Zangué, F. Villiéras and R. Kamga , (2014). Dépollution des eaux usées par les argiles alluviales. Editions à EUE d'un livre, Référence du livre : 978-613-1-59387-1 (ISBN 978-613-1-59387-1); ISBN-10: 6131593876; EAN: 9786131593871; Maison d'édition: Editions universitaires europeennes ;Site Web: http://www.editions-ue.com/; Publié le: $18-09-2014$

[4] Ahmad T, Rafatullah M, Ghazali A, Sulaiman O, Hashim R, Ahmad A (2011). Oil palm biomass based adsorbents for the removal of water pollutants - a review. J Environ Sci Health Part C 29:177-222

[5] Ahmad Tanweer, Mohammad Danish, Mohammad Rafatullah, Arniza Ghazali, Othman Sulaiman, Rokiah Hashim, Mohamad Nasir Mohamad Ibrahim, (2018). The use of date palm as a potential adsorbent for wastewater treatment: a review, Environ Sci Pollut Res (2012) 19:1464-1484 DOI 10.1007/s11356-011-0709-8.

[6] Arif Tasleem Jan , Mudsser Azam , Kehkashan Siddiqui , Arif Ali , Inho Choi and Qazi Mohd. Rizwanul Haq, (2015). Heavy Metals and Human Health: Mechanistic Insight into Toxicity and Counter Defense System of Antioxidants. International Journal of Molecular Sciences (ijms) 29592-29630. Int. J. Mol. Sci. 2015, 16, 29592-29630.

[7] Arwidsson Z, Elgh-Dalgren K, von Kronhelm T, Sjöberg R, Allard B, van Hees $\mathbf{P}$ (2010) Remediation of heavy metal contaminated soil washing residues with amino polycarboxylic acids. J Hazard Mater 173:697-704.

[8] Berthelot Y, Valton E, Auroy A, Trottier B, Robidoux PY (2008). Integration of toxicological and chemical tools to assess the bioavailability of metals and energetic compounds in contaminated soils. Chemosphere 74:166-177.

[9] Bridges, C.C.; Zalups, R.K. (2010). Transport of inorganic mercury and methylmercury in target tissues and organs. $J$. Toxicol. Environ. Health Crit. Rev. 2010, 13, 385-410.

[10] CACAR, 2003: Canadian Contaminants Assessment Report II, Sources, Occurrence, Trends and Pathways in the physical environment, Northern Contaminants program, Minister of Indian Affairs and Northern Development, Minister of Public Works and Government Services Canada, p.p. 332.

[11] Cao X, Dermatas D, Xu X, Shen G (2008). Immobilization of lead in shooting range soils by means of cement, quicklime, and phosphate amendments. Environ Sci Pollut Res Int 15:120-127.

[12] Carneiro, M.F.H.; Oliveira Souza, J.M.; Grotto, D.; Batista, B.L.; de Oliveira Souza, V.C.; Barbosa, F., Jr. (2014). A systemic study of the deposition and metabolism of mercury species in mce after exposure to low levels of Thimerosal (ethylmercury). Environ. Res. 2014, 134, 218-227.

[13] Chang, L.W. (1977) Neurotoxic effects of mercury: A review. Environ. Res. 1977, 14, 329-373.

[14] Chen, C.W.; Chen, C.F.; Dong, C.D. (2012). Distribution and Accumulation of Mercury in Sediments of Kaohsiung River Mouth, Taiwan. APCBEE Procedia 2012, 1, 153-158.
[15] Chrastný V, Komárek M, Hájek T (2010). Lead contamination of an agricultural soil in the vicinity of a shooting range. Environ Monit Assess 162:37-46.

[16] Coetzee, P.P., Coetzee, L.L., Puka, R., Mubenga, S., (2003). Charac-terisation of selected South African clays for defluoridation of natural waters. Water SA 29, 331-338.

[17] Da Costa, A.C.A., Antunes, W.M., Luna, A.S., Henriques, C.A., (2003). An evaluation of copper biosorption by a brown seaweed under optimized conditions. Electronic Journal of Biotechnology 6(3), 174-184.

[18] De Boer J.H., Linsen B.G. et Osinga T.J., (1996). Studies on pore systems in catalysts. VI. The universal curve. J. catalysis, Vol. 4, p 643-648

[19] Esmaili, A., Nasseri, A.H., Atash-Dehghan, R., (2003). Adsorption of lead and zinc ions from aqueous solutions by volcanic ash soil (VAS). In: Proceedings of the 8th Conference on Environment Science and Technology. Lemnos Island, Greece. pp. B193-B199.

[20] Geier, D.A.; King, P.G.; Hooker, B.S.; Dorea, J.G.; Kern, J.K.; Sykes, L.K.; Geier, M.R. (2015).Thimerosal Clinical,epidemiologic and biochemical studies. Clin. Chim. Acto 2015, 444, 212-220.

[21] Ho, Y.S., McKay, G., (1998). A two-stage batch sorption optimized design for dye removal to minimize contact time. Transactions of the Institution of Chemical Engineers Part B 76, 313-318.

[22] Ilyin I., Ryaboshapko A., Afinigenova O., Berg T., Hjellbrekke A.G., Lee D.S. (2002). Lead,cadmium and mercury transboundary pollution in 2000. MSC-E/CCC Technical Report $5 / 2002$.

[23] Ilyin I., Travnikov O., Ass W. and Ugerud H. Th. (2003). Heavy metals: transboundary pollution of the environment EMEP Status Report 2/2003. MSC-E, June, 2003. 40 pgs.

[24] Ilyin Ilia, Torun Berg, Sergey Dutchak, Jozef Pacyna, (2010). EMEP Assessment Report-Part I: 117-138. Chapter 7: Heavy Metals.

[25] Kadirvelu, K., Thamaraiselvi, K., Namasivayam, C., (2001). Adsorp-tion of nickel(II) from aqueous solution onto activated carbon prepared from coirpith. Separation and Purification Technology 24, 497-505.

[26] K. Sundar, R. Vidaya, Amitava Mukherjee and N. Chandrasekaran, (2010). High Chromium tolerant bacteria strains from palar river basin: Impact of tannery pollution. Research Journal of Environmental and Earth Sciences 2(2) : 112 117, 2010 ISSN : 2041-0492.

[27] McKay, G., Ko, D.C.K., Cheung, C.W., Choy, K.K.H., Porter, F.P., (2004). Sorption equilibria of metal ions on bone char Chemosphere 54 (3), 273-281.

[28] M. C. Basso, E. G. Cerrella, and A. L. Cukierman, (2002) Lignocellulosic Materials as Potential Biosorbents of Trace Toxic Metals from Wastewater. Programa de Investigación y Desarrollo de Fuentes Alternativas de Materias Primas y Energía (PINMATE), Departamento de Industrias, Facultad de Ciencias Exactas y Naturales, Universidad de Buenos Aires, Intendente Guiraldes 2620, Ciudad Universitaria, 1428 Buenos Aires, Argentina Ind. Eng. Chem. Res., 2002, 41 (15), pp 3580-3585 DOI: 10.1021/ie020023h Publication Date (Web): June 26, 2002 Copyright (C) 2002 American Chemical Society.

[29] Moon DH, Cheong KH, Kim TS, Khim J, Choi SB, Ok YS, Moon OR (2010) Stabilization of $\mathrm{Pb}$ contaminated army firing range soil using calcinated waste oyster shells. Korean Soc Environ Eng 32:1353-1358.

[30] Mosser R, Pironon J, Cathelineau M, Trouiller A (2001) Experimental illitization of smectite in a K-rich solution. Eur. J. Miner. 13(5):829-840.

[31] Naseem, R., Tahir, S.S., (2001). Removal of $\mathrm{Pb}$ (II) from aqueous/acidic solutions by using bentonite as an adsorbent. Water Research 35 (16), 3982-3986.

[32] Neaman A, Pelletier M, Villieras F (2003). The effects of exchanged cation, compression, heating and hydration on textural properties of bulk bentonite and its corresponding purified montmorillonite. Appl. Clay Sci. 22(4):153-168.

[33] Orumwense, F.F.O., (1996). Removal of lead from water by adsorption on a kaolinitic clay. Journal of Chemical Technology and Biotechnology 65, 363-369. 
[34] Sameeh A. Mansour*, Reham I. Mohamed and Amina R. Ali, (2016). Removal of heavy metals from aqueous solutions by means of agricultural wastes: assessments based on biological assay and chemical analysis. J.Bio.Innov 5(4), pp: 480-505, 2016|ISSN 2277-8330 (Electronic).

[35] Tryball, R.E., (1980). Mass Transfers Operations, third ed. McGraw, New York.

[36] Ulmanu, M., Anger, I., Lakatos, J., Aura, G., (2003). Contribution to some heavy metals removal from aqueous solution using peat. In: Proceedings of the First International Conference on Environmen-tal Research and Assessment. Bucharest, Romania, March 23-27, pp. 185-192.

[37] Uyanik, A., Çay, S., ÖzaŞI, K., (2004). Single and binary component adsorption of copper(II) and cadmium(II) from aqueous solutions using tea-industry waste. Separation and Purification Technology, 1-8.

[38] WHO, World Health Organization, (2011). Guidelines For Drinking Water Quality, Geneva, Switzerland, 4th edition, 2011.

[39] Yi, J., Rengaraj, S., Kim, Y., Joo, C.K., Choi, K., (2004). Batch adsorptive removal of copper ions in aqueous solutions by ion exchange resins: $1200 \mathrm{H}$ and IRN97H. Korean Journal of Chemical Engineering 21 (1), 187-194. 